\title{
Comparison of individual tree aboveground biomass estimation in community forests using allometric equation and expansion factor in Magetan, East Java, Indonesia
}

\author{
RAHMANTA SETIAHADI ${ }^{\vee}$ \\ Department of Agrotechnology, Faculty of Agriculture, Universitas Merdeka Madiun. Jl. Serayu 79 Madiun - 63133, East Java, Indonesia. \\ Tel./fax.: +62-351-464427, vemail: rahmanta_setiahadi@unmer-madiun.ac.id
}

Manuscript received: 18 July 2021. Revision accepted: 25 August 2021.

\begin{abstract}
Setiahadi R. 2021. Comparison of individual tree aboveground biomass estimation in community forests using allometric equation and expansion factor in Magetan, East Java, Indonesia. Biodiversitas 22: 3899-3909. The use of allometric equation and biomass expansion factor can facilitate more efficient tree biomass estimation. This study evaluates the accuracy of the allometric equation and expansion factor for quantifying the individual tree aboveground biomass in community forest tree species. Destructive sampling n on 120 trees from four different species: Falcataria moluccana, Melia azedarach, Swietenia macrophylla, and Tectona grandis. For each tree sample, aboveground biomass measured at every tree component, i.e., stem, branches, and leaves. The allometric equation developed using regression analysis with several predictor variables, such as diameter at breast height (D), squared dia meter at breast height combined with tree height $\left(\mathrm{D}_{2} \mathrm{H}\right)$, and $\mathrm{D}$ and $\mathrm{H}$ separately. On another side, the biomass expansion factor was calculated based on the total aboveground biomass and stem biomass ratio. The results found the highest mean aboveground biomass for all species are $M$. azedarach $(326.36 \pm 88.40 \mathrm{~kg}$ tree-1), S. macrophylla $(244.47 \pm 98.73 \mathrm{~kg}$ tree-1), $T$. grandis $(173.31 \pm 80.97 \mathrm{~kg}$ tree-1), and $F$. moluccana $(56.56 \pm 23.10 \mathrm{~kg}$ tree-1). The most significant average biomass expansion factor observed in M. azedarach (1.78 \pm 0.03 ), adhered by $T$. grandis (1.66 \pm 0.09$)$, S. macrophylla $(1.61 \pm 0.04)$, and $F$. moluccana $(1.59 \pm 0.06)$. The equation $\ln \hat{Y}=\operatorname{lna}+b x \ln (D)$ was best for estimating aboveground biomass in each tree component and a total of four species with an accuracy of more than $90 \%$.
\end{abstract}

Keywords: aboveground biomass, accurate quantification, allometric equation, biomass expansion factor, community forests

\section{INTRODUCTION}

Climate change mitigation currently becomes the most crucial challenge in sustainable forest management (Nunes et al. 2019), primarily in community forests. In this case, community forests expected to stabilize timber supply for industry development and minimize greenhouse gas emissions in the atmosphere (Setiahadi 2017). However, the fundamental role of community forests for carbon reduction highly depends on their productivity, wherein the accumulation of forest biomass plays an essential contribution in this process (Wirabuana et al. 2020). Several kinds of literature explain that biomass production is an attribute of forest ecosystems with a principal function in a biogeochemical cycle, mainly related to the carbon cycle (Reichstein et al. 2019; de Andrés 2019; Bouriaud et al. 2019; Nunes et al. 2020). Higher forest biomass indicates more excellent carbon storage (Han and Park 2020) since around $50 \%$ of biomass are composed of carbon element (Viera and Rodriquez-Soalleiro 2019; Besar et al. 2020; Sadono et al. 2020). Therefore, to evaluate community forests' strategic position for supporting climate change mitigation, the precise quantification of biomass is necessary to estimate carbon stock in community forests.

The accurate measurement of forest biomass is principally determined by the precise estimation of individual tree biomass (Altanzagas et al. 2019). Therefore, the implementation of destructive forest inventory methods can provide the most accurate result for biomass determination (Issa 2020). Nevertheless, this method requires high cost, long-time consumption and almost impossible to be conducted in a large area (Tetemke et al. 2019; Zhao et al. 2019). Moreover, destructive methods on a wide scale can decrease forest regeneration due to tree harvesting (Kora et al. 2019). Consequently, it needs to develop other strategies for supporting more efficient tree biomass quantification in community forests. The development of allometric equation and biomass expansion factor (BEF) can become practical solutions in facilitating the accurate estimation of individual tree biomass in community forests to reach this goal.

Many studies reported the allometric equation and BEF widely utilized to estimate individual tree biomass in forest ecosystems, both in tropics and subtropics (Krejza et al. 2017; Lisboa et al. 2018; Kim et al. 2019; Mahmood et al. 2020). However, comparing both techniques for supporting tree biomass estimation in community forests is rarely documented, especially in Indonesia. This condition is relatively different from other studies about the quantification of tree biomass in plantation forests, wherein the accuracy of both methods have evaluated simultaneously (Petersson et al. 2012; Seo et al. 2013; Taeroe et al. 2015). Those studies record the utilization of allometric equation substantially indicates a better accuracy than BEF for estimating tree biomass in plantation forests. 
The development of an allometric equation and BEF for calculating the individual tree biomass of Indonesian community forests is not easy and more complicated than plantation forests. Besides having variation in age distribution and tree growth (Boedhihartono 2017), Indonesian community forests also consist of various tree species with irregular pattern (Boedhihartono 2017; Wulandari et al. 2018). The circumstance is very different to plantation forests which dominated by monoculture species with uniform age distribution. This fact leads to determine whether the use of allometric equation and BEF can show good accuracy for quantifying tree biomass in Indonesian community forests.

Furthermore, if both methods present an accurate result, it is better to estimate the tree biomass of community forests in Indonesia. Respond to those questions; thus, this study designed to evaluate the accuracy of allometric equation and $\mathrm{BEF}$ for predicting the individual tree biomass of community forests tree species. The study conducted in Magetan District, Indonesia, due to this area had a large community forest and became one of the best community forests in East Java, Indonesia. Moreover, the study of allometric equation and BEF in this area is still limited. Previous studies generally only focused on constructing an allometric model for predicting the aboveground biomass of $T$. grandis. Dissimilar with the previous research, this study will develop an allometric equation and $\mathrm{BEF}$ for four species grown in Magetan community forests, i.e., F. moluccana, M. azedarach, $S$. macrophylla, and $T$. grandis. Therefore, this study determines the most efficient method for facilitating biomass estimation in community forests between the allometric equation and $\mathrm{BEF}$.

\section{MATERIALS AND METHODS}

\section{Study area}

Data collected from community forests around Magetan District, East Java, Indonesia (Figure 1). The community forest located at three different villages, namely Ngiliran, Jabung, and Bedagung. These areas had a geographic position of $7^{\circ} 30^{\prime} 34^{\prime \prime}$ to $7^{\circ} 47^{\prime} 49^{\prime \prime} \mathrm{S}$ and $111^{\circ} 10^{\prime} 54^{\prime \prime}$ to $111^{\circ} 30^{\prime} 46^{\prime \prime} \mathrm{E}$. The altitude ranged from 600 to $1,660 \mathrm{~m}$ above sea level. The topography was predominantly by hilly area with slope level approximately of $15-45 \%$. The average daily temperature reached nearly $24^{\circ} \mathrm{C}$ with a minimum temperature of $16^{\circ} \mathrm{C}$ and a maximum temperature of $26^{\circ} \mathrm{C}$. Annual rainfall varied from 1,600 to $3,000 \mathrm{~mm}$ year ${ }^{-1}$ during the last five years from 2016 to 2020. Most rainfall occurred in November and April. This area had a short dry period of around three months, from July to September. The mean air humidity in this location was $85 \%$, with a minimum of $77 \%$ and a maximum of $89 \%$. Latosols dominated soil type with moderate organic matter. Soil acidity categorized into slightly acid, with a pH of 5.5 to 6.0.

\section{Data collection}

The data collection was conducted from June to September 2020. Destructive sampling was carried out on
120 trees from four different species, i.e., T. grandis, $S$. macrophylla, M. azedarach, and $F$. moluccana. Those species were primary plants cultivated by the community at Magetan District. In addition, having a prospective market, those plants also had good adaptability with environmental conditions in this site. The number of sample trees for each species was 30 samples (Table 1). The selected the samples by considering tree diameter distribution to obtain the balance plant dimension from small to big trees (Guendehou et al. 2012). In this study, tree diameter categorized into four classes, i.e., smaller than $10 \mathrm{~cm}$, $10-20 \mathrm{~cm}, 21-30 \mathrm{~cm}$, and bigger than $30 \mathrm{~cm}$. Constructed the classification of tree diameter based on the previous study, which focused on developing an allometric model in community forests in Indonesia (Wirabuana et al. 2020).

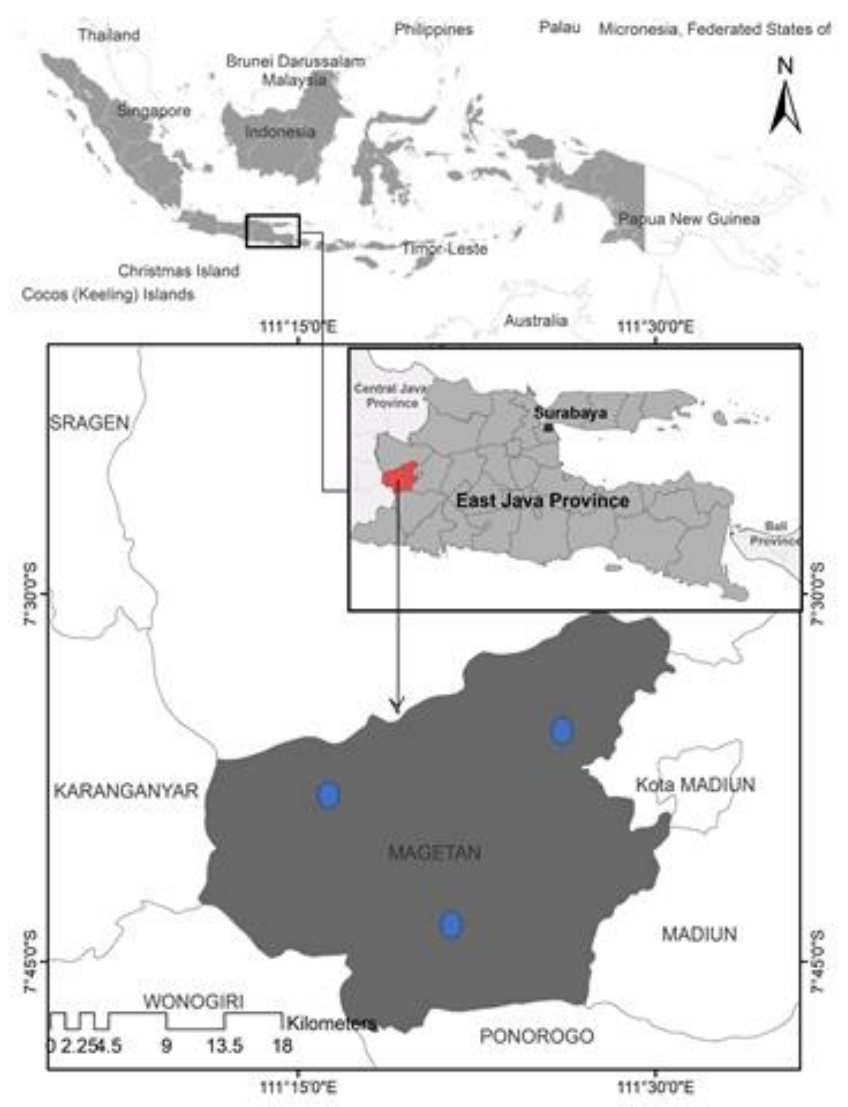

Figure 1. Distribution of community forests as the study area in Magetan District. The blue circle indicated a sampling location.

Table 1. Total sample trees of every species collected from three different sites of community forests in Magetan District

\begin{tabular}{|c|c|c|c|c|}
\hline \multirow[t]{2}{*}{ Species } & \multicolumn{3}{|c|}{$\begin{array}{c}\text { Number of sample trees in } \\
\text { each location }\end{array}$} & \multirow{2}{*}{$\begin{array}{l}\text { The total } \\
\text { sample for } \\
\text { each species }\end{array}$} \\
\hline & Ngilira & Jabun & Bedagung & \\
\hline S. macrophylla & 10 & 10 & 10 & 30 \\
\hline T. grandis & 10 & 10 & 10 & 30 \\
\hline F. moluccana & 10 & 10 & 10 & 30 \\
\hline M. azedarach & 10 & 10 & 10 & 30 \\
\hline $\begin{array}{l}\text { The total sample of } \\
\text { each location }\end{array}$ & 40 & 40 & 40 & 120 \\
\hline
\end{tabular}


The implementation of destructive sampling was done step by step in a chronological manner (Figure 2). The diameter at breast height $(\mathrm{cm})$ and tree height $(\mathrm{m})$ for each tree were undertaken before the selected tree was felled. The tree diameter was measured at $1.3 \mathrm{~m}$ from aboveground using a diameter tape. While the tree height was estimated from aboveground to top crown using a hagameter. After recording those data, the sample tree was felled using a chain saw with a stump size at $0.1 \mathrm{~m}$ from aboveground ( $\mathrm{Lu}$ et al. 2018). Then, separated tree components into three parts, i.e., stem, branches, and foliage (Altanzagas et al. 2019). The wood volume of each selected tree calculated using the Smallian formula as shown in the equation below:

$$
V=\frac{\pi}{8}\left(D_{L}^{2}+D_{s}^{2}\right) L
$$

Where: $V$ was stem volume $\left(\mathrm{m}^{3}\right), D_{L}$ showed the size of stem diameter at the large end $(\mathrm{cm}), D$ s indicated the extent of stem diameter at the small end $(\mathrm{cm})$, and $L$ was the length of stem $(\mathrm{m})$.

Afterwards, the fresh weight of every tree component was quantified using a hanging balance in the field. Approximately $500 \mathrm{~g}$ sub-sample from each part was taken and brought to the laboratory for dried (Wirabuana et al. 2019). The drying process carried out using an oven at $70^{\circ} \mathrm{C}$ for 48 hours before weighted for measuring its dry weight (Hakamada et al. 2017). Then, the biomass of the sub-sample was determined based on its constant dry weight. Total biomass in each tree component of sample trees calculated using this formula:

$$
W_{c}=\left(\frac{F W_{c}}{F W_{s}}\right) D W_{s}
$$

Where: $W_{c}$ indicated biomass of tree component $(\mathrm{kg})$, $F W_{c}$ was the fresh weight of tree component $(\mathrm{kg}), F W_{s}$ was the fresh weight of sub-sample component $(\mathrm{g})$, and $D W_{s}$ signified dry weight of sub-sample component $(\mathrm{g})$. Total aboveground biomass for the individual tree $\left(W_{t}\right)$ calculates by summing the biomass from the stem $(W s)$, branches $\left(W_{b}\right)$, and foliage $\left(W_{f}\right)$. Then, biomass expansion factor $(B E F)$ was computed by following this equation:

$$
B E F=\frac{W_{t}}{W_{s}}
$$

Furthermore, the sub-sample of the stem extracted into the cube. The size of the dimension for every cube was 50 $\mathrm{mm} \times 50 \mathrm{~mm} \times 50 \mathrm{~mm}$. Then, the dry weight of the cube was measured using an analytical scale. To determine the cube volume, the cube immersed into $100 \mathrm{ml}$ of water in a measuring cup. The computed cube volume based on the increment of water level in the measuring cup. This formula calculated the wood density of every sample tree:

$$
\rho=\frac{C_{w}}{C_{v}}
$$

Where: $\rho$ was wood density $\left(\mathrm{g} \mathrm{cm}^{-3}\right), C_{w}$ indicated the weight of cube $(\mathrm{g})$, and $C_{v}$ represented the volume of the cube $\left(\mathrm{cm}^{3}\right)$. Determined the specific wood density for every species based on the average wood density from the selected sample tree in each species

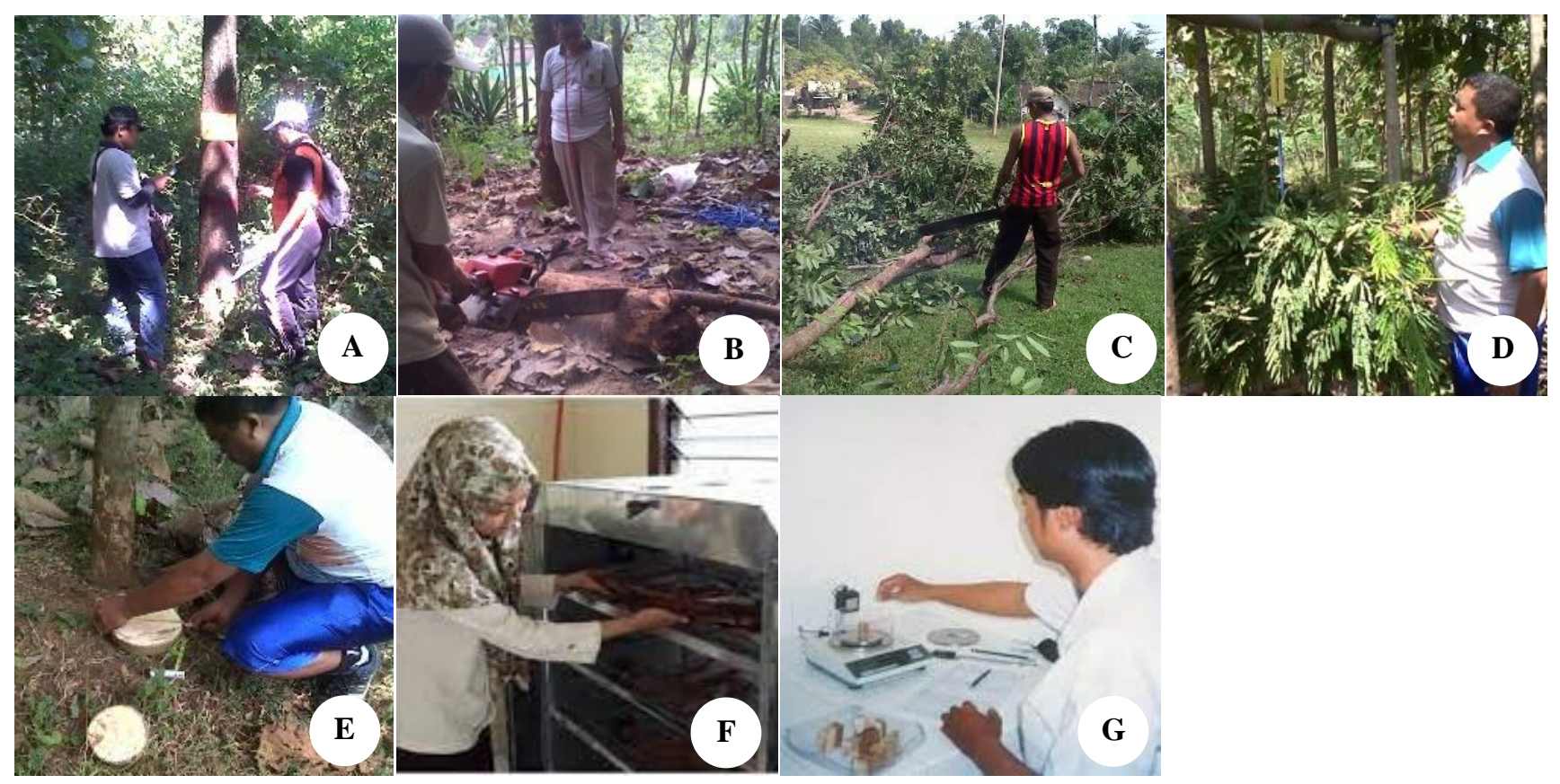

Figure 2. Flow process of destructive sampling for data collection: A. Measuring sample trees for diameter at breast height and tree height; B. Felling selected trees using a chain saw; C. Separating tree component; D. Weighting the fresh weight of leaf component; E. Collecting sub-sample; F. Drying sub-sample in the laboratory; G. Weighting the dry-weight for biomass determination 


\section{Data analysis}

Statistical analysis was processed using a significant level of 5\%. A descriptive test conducted to find the minimum, maximum, mean, standard deviation, and standard error (Mishra et al. 2019). From the results of destructive sampling for each observation variable. Then, the normality of data observation tested using the ShapiroWilk test (Ghasemi and Zahediasi 2012). For developing allometric equations, data divided into two groups. The first group used the first group to construct the fit model (20 sample trees for each species), while the second group validated the fit model (10 sample trees for each species). Several previous studies have published that the fit model for allometric equation could be developed using a low number of tree samples (Ketterings et al. 2001; Stas et al. 2017).

The developed an allometric equation designed for four species, established in community forests at Magetan District. Testing three allometric models to measure aboveground biomass. Each tree component and the total of each species used several independent variables to formulate the equation, namely diameter at breast height (D), diameter squared at chest height combined with tree height $\left(\mathrm{D}_{2} \mathrm{H}\right)$, and $\mathrm{D}$ and $\mathrm{H}$ separately (Xue et al. 2016; Altanzagas et al. 2019; Wirabuana et al. 2020). The detailed equations for constructing those models presented below:

$$
\begin{gathered}
\hat{Y}=a D^{b} \\
\hat{Y}=a\left(D^{2} H\right)^{b} \\
\hat{Y}=a D^{b} H^{c}
\end{gathered}
$$

Where: $\hat{Y}$ indicated the estimated parameters while $a, b$, and $c$ were the fitted coefficient.

The utilization of a non-linear growth model based on arithmetic units did not have constant error variance overall observation in most cases (Altanzagas et al. 2019). It was frequently called heteroscedasticity. To minimize the effect of heteroscedasticity, the data transformation in the form of natural logs is carried out periodically to convert the nonlinear model into linear regression when determining the parameters for the equation (He et al. 2018). Thereby, the equation 5 to 7 were changed into the equations as shown below:

$$
\begin{aligned}
& \ln \hat{Y}=\ln a+b \times \ln D \\
& \ln \hat{Y}=\ln a+b \times \ln \left(D^{2} H\right) \\
& \ln \hat{Y}=\ln a+b \times \ln D+c \times \ln H
\end{aligned}
$$

Where: $\ln \hat{Y}$ described the predicted values of aboveground biomass from every tree component and total in the logarithmic unit and $a, b, c$ were the fitted parameters.

Several previous references have reported the benefit of log-transformed linear regression for modelling tree characteristics (Xue et al. 2016; Altanzagas et al. 2019; Wirabuana et al. 2020). Nevertheless, the utilization of antilog transformation of the estimated logarithmic values into arithmetic units leads to a systematic bias that the correction factor could commonly correct. The equation for calculating a correction factor shown below:

$$
C F=\exp \left(\frac{R M S E^{2}}{n}\right)
$$

Where: $C F$ was the correction factor and RMSE was the root mean square error from the logarithmic regression.

Determine the best allometric equation for estimating aboveground biomass in every species. Selected several indicators to evaluate developed models, namely the fitted parameters $(a, b, c)$, coefficient of determination $\left(R^{2}\right)$, Akaike information criterion (AIC), root mean square error (RMSE), and mean absolute bias (MAB) (González-Garcia et al. 2013; Ekoungoulou et al. 2013). Used the indicator of $\mathrm{R}^{2}$ and AIC to assess the model fitting, while RMSE and MAB were applied to examine the validation stage (Sadono et al. 2021). Details formula for calculating those parameters were presented below:

$$
\begin{aligned}
& R^{2}=1-\left(\frac{\sum_{i=1}^{n}(\ln Y-\ln \bar{Y})^{2}}{\sum_{i=1}^{n}(\ln Y-\ln \hat{Y})^{2}}\right) \\
& A I C=n \log \left(\frac{R S S}{n}\right)+2 k+\frac{2 k+(k+1)}{n-k-1} \\
& R M S E=\sqrt{\frac{\sum_{i=1}^{n}(\ln Y-\ln Y)^{2}}{(n-p-1)}} \\
& M A B=\sum \frac{(|\ln Y-\ln Y|)}{n}
\end{aligned}
$$

Where: $\ln Y$ was the actual $\log$-transformed parameters, $\ln \hat{Y}$ indicated the estimated log-transformed from the fitted model, $n$ showed the sample size, $\ln \overline{\bar{Y}}$ represented the mean actual $\log$-transformed parameters, $R^{2}$ was coefficient of determination, RSS was the residual sum of squares from the fitted model, $p$ indicated the number of terms in the model, and $k$ was the number of parameters.

The best allometric equation had to fulfil several requirements, including significant fitted parameters, high $R^{2}$ value, small AIC, RMSE, and MAB. Besides considering statistic parameters for evaluating the best model, this study also deliberates additional criteria, namely simplicity (Wirabuana et al. 2020). It was important since the species composition of community forests in Magetan composed of many tree species which had irregular distribution in growth, age, and spacing. Consequently, tree height measurement in community forests was relatively difficult due to the multi-layer crown structure. However, this criterion was only utilized if the gap accuracy between single predictor and multiple predictors were lower than 5\% (Sadono et al. 2021). 
After finding the best allometric equation for each species. The model was used to quantify total aboveground biomass for every tree sample. Then, biomass estimation using an allometric equation compared by the outcome of biomass prediction using $B E F$. The mathematical formula for estimating aboveground tree biomass using $B E F$ expressed below (Krisnawati et al. 2012):

$$
A G B=V \rho B E F
$$

Where: $A G B$ was total aboveground biomass $(\mathrm{kg}), V$ represented stem volume $\left(\mathrm{m}^{3}\right), \rho$ indicated the mean wood density for each species ( $\mathrm{kg} \mathrm{m}-3)$, and $B E F$ was biomass expansion factor for every species. We determined the most accurate method based on the difference between estimation and actual measurement, which examined using a t-test.

\section{RESULTS AND DISCUSSION}

\section{Distribution of selected tree samples}

Summarized results of the observation showed that tree samples' distribution was not similar in every diameter class for each species (Table 2). As an explanation, the highest number of tree samples in $M$. azedarach recorded in a diameter class of $21-30 \mathrm{~cm}$. This condition was different from other species, where the most significant tree samples observed in a diameter class of $11-20 \mathrm{~cm}$.
Interestingly, S. macrophylla and $M$. azedarach had the lowest number of tree samples at the smallest diameter class $(<10 \mathrm{~cm})$ while $T$. grandis and $F$. moluccana had the minor tree samples at the most significant diameter class (> $31 \mathrm{~cm})$. Nevertheless, for total selected tree samples, the highest number of tree samples were found at a diameter class of 11-20 cm (42 trees), followed by the diameter class of $21-30 \mathrm{~cm}$ (37 trees), $<10 \mathrm{~cm}$ (21 trees), and $>31$ $\mathrm{cm}$ (20 braids). This study observed the most oversized mean tree diameter from four species was noted in $M$. azedarach $(26.3 \pm 4.3 \mathrm{~cm})$, followed by $S$. macrophylla $(23.4 \pm 4.3 \mathrm{~cm}), T$. grandis $(19.8 \pm 3.8 \mathrm{~cm})$, and $F$. moluccana $(19.7 \pm 3.8 \mathrm{~cm})$ (Table 3$)$. A similar pattern also exhibited by the average tree height of those species, in which the most significant mean tree height was recorded in $M$. azedarach $(10.7 \pm 1.2 \mathrm{~m})$, followed by $S$. macrophylla $(9.0 \pm 1.4 \mathrm{~m}), T$. grandis $(8.2 \pm 0.9 \mathrm{~m})$, and $F$. moluccana $(7.3 \pm 1.6 \mathrm{~cm})$. It indicated that there was a relationship between tree diameter and tree height.

Table 2. Distribution of tree samples from four different species in every diameter class

\begin{tabular}{lllll}
\hline \multirow{2}{*}{ Species } & \multicolumn{5}{l}{ Number of sample trees } \\
\cline { 2 - 5 } & $\leq \mathbf{1 0} \mathbf{~ c m}$ & $\mathbf{1 1 - 2 0} \mathbf{~ c m}$ & $\mathbf{2 1 - 3 0} \mathbf{~ c m}$ & $\mathbf{2 3 1} \mathbf{~ c m}$ \\
\hline S. macrophylla & 3 & 11 & 10 & 6 \\
T. grandis & 8 & 10 & 8 & 4 \\
F. moluccana & 5 & 13 & 9 & 3 \\
M. azedarach & 5 & 8 & 10 & 7 \\
Total & 21 & 42 & 37 & 20 \\
\hline
\end{tabular}

Table 3. Descriptive statistics of data from the outcome of destructive sampling in four species at community forests around Magetan District, Indonesia

\begin{tabular}{|c|c|c|c|c|c|c|c|}
\hline Species & Value & $\mathrm{D}(\mathbf{c m})$ & $\mathbf{H}(\mathbf{c m})$ & Stem (kg) & Branch (kg) & Foliage (kg) & Total AGB (kg) \\
\hline \multirow[t]{5}{*}{ S. macrophylla } & Mean & 23.4 & 9.0 & 152.74 & 61.90 & 29.84 & 244.47 \\
\hline & SD & 10.0 & 3.4 & 145.75 & 59.04 & 26.71 & 231.06 \\
\hline & SE & 4.3 & 1.4 & 62.28 & 25.23 & 11.41 & 98.73 \\
\hline & Min & 8.9 & 4.8 & 9.02 & 4.68 & 2.50 & 16.62 \\
\hline & Max & 41.4 & 15.6 & 486.54 & 191.28 & 86.67 & 764.50 \\
\hline \multirow[t]{5}{*}{ T. grandis } & Mean & 19.8 & 8.2 & 101.31 & 65.31 & 6.68 & 173.31 \\
\hline & SD & 9.6 & 2.2 & 108.38 & 75.17 & 6.39 & 189.51 \\
\hline & SE & 4.1 & 0.9 & 46.31 & 32.12 & 2.73 & 80.97 \\
\hline & Min & 8.9 & 4.8 & 11.83 & 4.90 & 0.42 & 17.99 \\
\hline & Max & 40.4 & 13.0 & 391.58 & 271.96 & 22.73 & 686.26 \\
\hline \multirow[t]{5}{*}{ F. moluccana } & Mean & 19.7 & 7.3 & 36.95 & 13.24 & 6.37 & 56.56 \\
\hline & SD & 8.9 & 1.6 & 36.95 & 11.66 & 5.74 & 54.12 \\
\hline & SE & 3.8 & 0.7 & 15.8 & 5.0 & 2.5 & 23.1 \\
\hline & Min & 5.4 & 4.6 & 1.17 & 0.06 & 0.39 & 1.62 \\
\hline & Max & 40.1 & 11.1 & 148.77 & 47.24 & 22.34 & 218.35 \\
\hline \multirow[t]{5}{*}{ M. azedarach } & Mean & 26.3 & 10.7 & 179.89 & 121.23 & 25.25 & 326.36 \\
\hline & SD & 10.1 & 2.8 & 111.60 & 80.40 & 16.11 & 206.89 \\
\hline & SE & 4.3 & 1.2 & 47.69 & 34.35 & 6.88 & 88.40 \\
\hline & Min & 6.4 & 6.3 & 10.63 & 4.79 & 1.77 & 17.18 \\
\hline & Max & 42.3 & 16.8 & 404.72 & 288.14 & 51.69 & 744.55 \\
\hline
\end{tabular}




\section{The biomass accumulation, wood density, and BEF}

The accumulation of aboveground biomass performed on every species highly varied in the community forests around Magetan. The greatest mean AGB was found in $M$. azedarach $(326.36 \pm 88.40 \mathrm{~kg}$ tree- 1$)$, followed by $S$. macrophylla $(244.47 \pm 98.73 \mathrm{~kg}$ tree-1), $T$. grandis $(173.31+80.97 \mathrm{~kg}$ tree-1), and F. moluccana $(56.56+54.12$ $\mathrm{kg}$ tree-1) (Table 3). Our study documented more than $50 \%$ aboveground biomass in each species allocated in the stem (Table 4). Meanwhile, the distribution of biomass inbranch and foliage for each was approximately (24-36\%) and (4-13\%). These findings demonstrated the biomass proportion at individual trees gradually declined from stem to foliage for each species.

Even though the most significant biomass distribution accumulated in the stem, this study discovered the trend of biomass proportion across diameter class was not similar for each of the four species (Figure 3). For T. grandis and $M$. azedarach, the relative contribution of stem biomass to the total AGB declined from the smallest-diameter class $(<10 \mathrm{~cm})$ to the largest-diameter level $(>31 \mathrm{~cm})$. A similar pattern also observed in the trend of leaves biomass proportion to the total AGB. The relative contribution of leaves biomass gradually decreased along with the diameter class increment. It caused the increasing relative contribution of branch biomass to the total AGB following the rising diameter classes. In contrast, the proportion of stem biomass to the total AGB in S. macrophylla and $F$. moluccana improved from the lowest-diameter level $(<10$ $\mathrm{cm})$ to the biggest diameter level $(>31 \mathrm{~cm})$. Nevertheless, stem biomass's relative contribution slightly declined at the large-diameter class for $S$. macrophylla $(21-30 \mathrm{~cm})$ and the medium-diameter class for $F$. moluccana $(11-20 \mathrm{~cm})$. It caused by the increasing relative contribution of branch biomass at the diameter classes.

Our study confirmed the wood density and BEF from four species relatively varied (Table 5). The highest mean wood density was found in T. grandis $(628.4 \pm 63.5 \mathrm{~kg} \mathrm{~m}-$ 3), followed by $M$. azedarach $(556.2 \pm 163.7 \mathrm{~kg} \mathrm{~m}-3), S$.

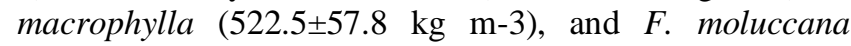
(512.9 $\pm 106.2 \mathrm{~kg} \mathrm{~m}-3)$. Among those species, M. azedarach was the species that had the greatest average $\mathrm{BEF}$ $(1.78 \pm 0.07)$. The second rank occupied by $T$. grandis (1.66 \pm 0.22$)$, followed by $S$. macrophylla $(1.61 \pm 0.10)$ and $F$. moluccana $(1.59 \pm 0.14)$. These results indicated that $F$. moluccana became the species with the lowest value of wood density and BEF.

\section{The allometric equation for estimating AGB}

Tested three candidate log-transformed allometric equations for estimating aboveground biomass. Perform in each component and total from four species. The outcomes of regression analysis showed all equations had good fits $(\mathrm{P}<0.05)$ (Table 6). However, the most accurate models for predicting AGB biomass in each component and total for each species was relatively different. For example, the use of equation "ln $\hat{Y}=\ln a+b \times \ln D$ " provided the highest accuracy (R2) for estimating stem biomass and total AGB in F. moluccana and M. azedarach, for the foliage and branch biomass of $S$. macrophylla, and the branch biomass of F. moluccana.

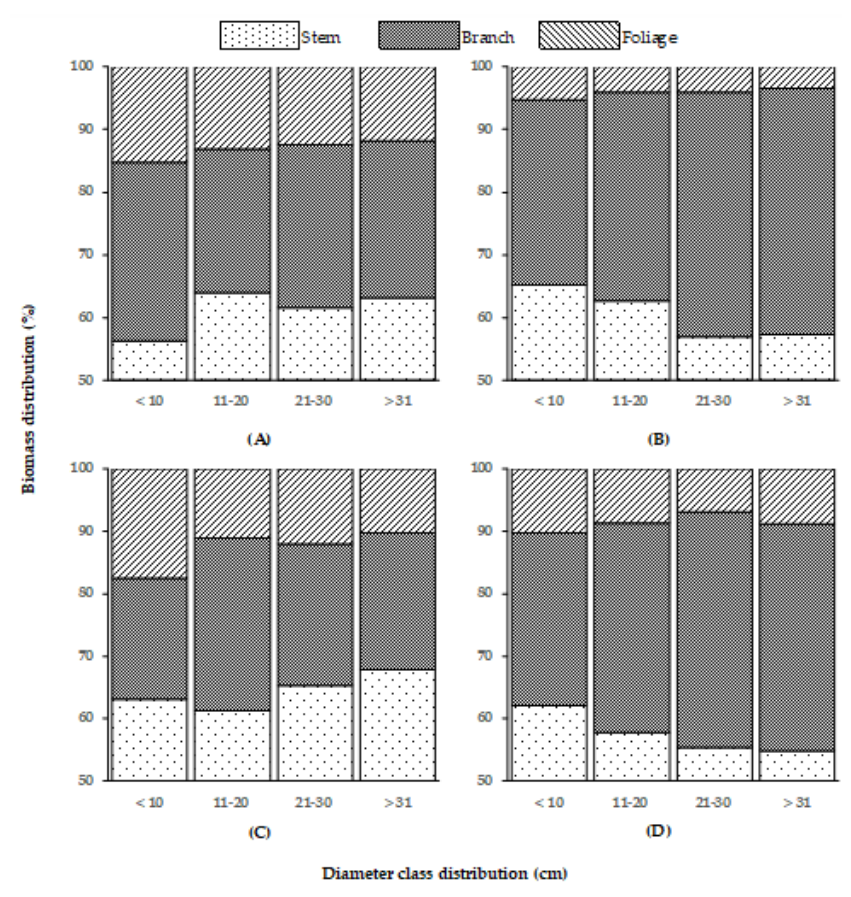

Figure 3. Biomass distribution in every tree component from different species at community forests across the diameter class

Table 5. Wood density and BEF from four different species at community forests

\begin{tabular}{lcccccc}
\hline \multirow{2}{*}{ Species } & \multicolumn{2}{c}{ Wood density $\left(\mathbf{k g ~ m}^{-\mathbf{3}}\right)$} & \multicolumn{3}{c}{ BEF } \\
\cline { 2 - 7 } & Mean & SD & Range & Mean & SD & Range \\
\hline S.macrophylla & 522.5 & 57.8 & $430-607$ & 1.61 & 0.10 & $1.41-1.84$ \\
T. grandis & 628.4 & 63.5 & $504-714$ & 1.66 & 0.22 & $1.28-2.51$ \\
F. moluccana & 512.9 & 106.2 & $320-649$ & 1.59 & 0.14 & $1.38-2.00$ \\
M. azedarach & 556.2 & 163.7 & $313-821$ & 1.78 & 0.07 & $1.61-1.85$ \\
\hline
\end{tabular}

Table 4. Ratio of stem, branch, and foliage biomass to the total aboveground biomass of the sample trees for every species

\begin{tabular}{lccccccccc}
\hline \multirow{1}{*}{ Species } & \multicolumn{3}{c}{ Stem biomass/AGB } & \multicolumn{2}{c}{ Branch biomass/AGB } & \multicolumn{3}{c}{ Foliage biomass/AGB } \\
\cline { 2 - 10 } & Mean & SD & Range & Mean & SD & Range & Mean & SD & Range \\
\hline S. macrophylla & 0.62 & 0.04 & $0.54-0.71$ & 0.25 & 0.03 & $0.17-0.31$ & 0.13 & 0.01 & $0.11-0.16$ \\
T. grandis & 0.61 & 0.07 & $0.40-0.78$ & 0.35 & 0.06 & $0.20-0.54$ & 0.04 & 0.02 & $0.02-0.11$ \\
F. moluccana & 0.64 & 0.05 & $0.50-0.72$ & 0.24 & 0.07 & $0.04-0.44$ & 0.12 & 0.04 & $0.06-0.24$ \\
M. azedarach & 0.56 & 0.02 & $0.54-0.62$ & 0.36 & 0.04 & $0.27-0.41$ & 0.08 & 0.02 & $0.04-0.11$ \\
\hline
\end{tabular}


Table 6. Parameter estimates and model evaluation statistics of each allometric equation for every tree component and total AGB from four species in community forests around Magetan.

\begin{tabular}{|c|c|c|c|c|c|c|c|c|c|}
\hline Biomass component & Equations* & Ina & $\mathbf{b}$ & c & $\mathbf{R}^{2}$ & AIC & MAB & RMSE & $\mathbf{C F}$ \\
\hline \multicolumn{10}{|l|}{ S. macrophylla } \\
\hline \multirow[t]{3}{*}{ Stem } & $\ln \hat{Y}=\ln a+b \ln D$ & -3.497 & 2.605 & - & 0.998 & -5.938 & 0.037 & 0.051 & 1.001 \\
\hline & $\ln \hat{\mathrm{Y}}=\ln \mathrm{a}+\mathrm{b} \ln \left(\mathrm{D}^{2} \mathrm{H}\right)$ & 5.374 & 0.939 & - & 0.991 & -4.302 & 0.091 & 0.117 & 1.007 \\
\hline & $\ln \hat{Y}=\ln a+b \ln D+c \ln H$ & -3.547 & 2.803 & -0.260 & 0.999 & -6.099 & 0.031 & 0.047 & 1.001 \\
\hline \multirow[t]{3}{*}{ Branch } & $\ln \hat{Y}=\ln a+b \ln D$ & -4.382 & 2.592 & - & 0.975 & -3.244 & 0.114 & 0.198 & 1.020 \\
\hline & $\ln \hat{\mathrm{Y}}=\ln \mathrm{a}+\mathrm{b} \ln \left(\mathrm{D}^{2} \mathrm{H}\right)$ & 4.447 & 0.937 & - & 0.975 & -3.239 & 0.131 & 0.198 & 1.020 \\
\hline & $\ln \hat{Y}=\ln a+b \ln D+c \ln H$ & -4.295 & 2.246 & 0.456 & 0.976 & -3.221 & 0.119 & 0.197 & 1.020 \\
\hline \multirow[t]{3}{*}{ Foliage } & $\ln \hat{Y}=\ln a+b \ln D$ & -4.576 & 2.442 & - & 0.986 & -3.939 & 0.096 & 0.140 & 1.010 \\
\hline & $\ln \hat{Y}=\ln a+b \ln \left(D^{2} H\right)$ & 3.739 & 0.881 & - & 0.982 & -3.697 & 0.125 & 0.158 & 1.013 \\
\hline & $\ln \hat{Y}=\ln a+b \ln D+c \ln H$ & -4.564 & 2.396 & 0.060 & 0.986 & -3.873 & 0.097 & 0.142 & 1.010 \\
\hline \multirow[t]{3}{*}{ Total AGB } & $\ln \hat{\mathbf{Y}}=\ln \mathbf{a}+\mathbf{b} \ln D$ & -2.935 & 2.577 & - & 0.996 & -5.167 & 0.051 & 0.076 & 1.003 \\
\hline & $\ln \hat{\mathrm{Y}}=\ln \mathrm{a}+\mathrm{b} \ln \left(\mathrm{D}^{2} \mathrm{H}\right)$ & 5.840 & 0.929 & - & 0.991 & -4.318 & 0.094 & 0.116 & 1.007 \\
\hline & $\ln \hat{Y}=\ln a+b \ln D+c \ln H$ & -2.945 & 2.615 & -0.051 & 0.996 & -5.104 & 0.050 & 0.077 & 1.003 \\
\hline \multicolumn{10}{|l|}{ T. grandis } \\
\hline \multirow[t]{3}{*}{ Stem } & $\ln \hat{Y}=\ln a+b \ln D$ & -2.404 & 2.250 & - & 0.964 & -3.086 & 0.122 & 0.214 & 1.023 \\
\hline & $\ln \hat{Y}=\ln a+b \ln \left(D^{2} H\right)$ & 5.327 & 0.911 & - & 0.972 & -3.336 & 0.120 & 0.189 & 1.018 \\
\hline & $\ln \hat{Y}=\ln a+b \ln D+c \ln H$ & -3.022 & 1.854 & 0.847 & 0.972 & -3.271 & 0.117 & 0.192 & 1.019 \\
\hline \multirow[t]{3}{*}{ Branch } & $\ln \hat{Y}=\ln a+b \ln D$ & -4.020 & 2.611 & - & 0.986 & -3.745 & 0.084 & 0.154 & 1.012 \\
\hline & $\ln \hat{Y}=\ln a+b \ln \left(D^{2} H\right)$ & 4.934 & 1.044 & - & 0.970 & -2.964 & 0.156 & 0.228 & 1.026 \\
\hline & $\ln \hat{\mathrm{Y}}=\ln \mathrm{a}+\mathrm{b} \ln \mathrm{D}+\mathrm{c} \ln \mathrm{H}$ & -3.716 & 2.806 & -0.417 & 0.987 & -3.788 & 0.081 & 0.148 & 1.011 \\
\hline \multirow[t]{3}{*}{ Foliage } & $\ln \hat{Y}=\ln a+b \ln D$ & -5.012 & 2.222 & - & 0.878 & -1.785 & 0.232 & 0.410 & 1.088 \\
\hline & $\ln \hat{Y}=\ln a+b \ln \left(D^{2} H\right)$ & 2.604 & 0.886 & - & 0.858 & -1.635 & 0.274 & 0.442 & 1.103 \\
\hline & $\ln \hat{Y}=\ln a+b \ln \mathrm{D}+\mathrm{c} \ln \mathrm{H}$ & -4.551 & 2.518 & -0.632 & 0.882 & -1.753 & 0.215 & 0.411 & 1.088 \\
\hline \multirow[t]{3}{*}{ Total AGB } & $\ln \hat{\mathbf{Y}}=\ln \mathbf{a}+\mathbf{b} \ln \mathrm{D}$ & -2.222 & 2.361 & - & 0.985 & -3.852 & 0.079 & 0.146 & 1.011 \\
\hline & $\ln \hat{Y}=\ln a+b \ln \left(D^{2} H\right)$ & 5.883 & 0.951 & - & 0.982 & -3.692 & 0.109 & 0.158 & 1.013 \\
\hline & $\ln \hat{Y}=\ln a+b \ln \mathrm{D}+\mathrm{c} \ln \mathrm{H}$ & -2.470 & 2.202 & 0.340 & 0.986 & -3.866 & 0.081 & 0.143 & 1.010 \\
\hline \multicolumn{10}{|l|}{ F. moluccana } \\
\hline \multirow[t]{3}{*}{ Stem } & $\ln \hat{Y}=\ln a+b \ln D$ & -3.827 & 2.399 & - & 0.991 & -4.364 & 0.067 & 0.113 & 1.006 \\
\hline & $\ln \hat{\mathrm{Y}}=\ln \mathrm{a}+\mathrm{b} \ln \left(\mathrm{D}^{2} \mathrm{H}\right)$ & 4.546 & 0.991 & - & 0.984 & -3.765 & 0.124 & 0.152 & 1.012 \\
\hline & $\ln \hat{Y}=\ln a+b \ln D+c \ln H$ & -3.721 & 2.452 & -0.132 & 0.991 & -4.309 & 0.061 & 0.114 & 1.007 \\
\hline \multirow[t]{3}{*}{ Branch } & $\ln \hat{Y}=\ln a+b \ln D$ & -5.308 & 2.558 & - & 0.846 & -1.236 & 0.324 & 0.540 & 1.157 \\
\hline & $\ln \hat{Y}=\ln a+b \ln \left(D^{2} H\right)$ & 3.621 & 1.056 & - & 0.838 & -1.186 & 0.359 & 0.553 & 1.165 \\
\hline & $\ln \hat{\mathrm{Y}}=\ln \mathrm{a}+\mathrm{b} \ln \mathrm{D}+\mathrm{c} \ln \mathrm{H}$ & -5.058 & 2.683 & -0.309 & 0.846 & -1.172 & 0.318 & 0.549 & 1.162 \\
\hline \multirow[t]{3}{*}{ Foliage } & $\ln \hat{\mathbf{Y}}=\ln \mathbf{a}+\mathbf{b} \ln D$ & -4.715 & 2.126 & - & 0.973 & -3.489 & 0.120 & 0.175 & 1.015 \\
\hline & $\ln \hat{Y}=\ln a+b \ln \left(D^{2} H\right)$ & 2.702 & 0.876 & - & 0.960 & -3.104 & 0.166 & 0.212 & 1.023 \\
\hline & $\ln \hat{Y}=\ln a+b \ln D+c \ln H$ & -4.282 & 2.342 & -0.535 & 0.975 & -3.504 & 0.102 & 0.171 & 1.015 \\
\hline \multirow[t]{3}{*}{ Total AGB } & $\ln \hat{Y}=\ln a+b \ln D$ & -3.195 & 2.338 & - & 0.980 & -3.588 & 0.098 & 0.166 & 1.014 \\
\hline & $\ln \hat{Y}=\ln a+b \ln \left(D^{2} H\right)$ & 4.968 & 0.966 & - & 0.973 & -3.303 & 0.152 & 0.192 & 1.019 \\
\hline & $\ln \hat{Y}=\ln a+b \ln D+c \ln H$ & -3.133 & 2.370 & -0.077 & 0.980 & -3.523 & 0.095 & 0.169 & 1.014 \\
\hline \multicolumn{10}{|l|}{ M. azedarach } \\
\hline \multirow[t]{3}{*}{$\begin{array}{l}\text { M. azeaaracn } \\
\text { Stem }\end{array}$} & $\ln \hat{Y}=\ln a+b \ln D$ & -1.256 & 1.935 & - & 0.998 & -5.992 & 0.035 & 0.050 & 1.001 \\
\hline & $\ln \hat{Y}=\ln a+b \ln \left(D^{2} H\right)$ & 5.291 & 0.783 & - & 0.994 & -5.026 & 0.070 & 0.081 & 1.003 \\
\hline & $\ln \hat{\mathrm{Y}}=\ln \mathrm{a}+\mathrm{b} \ln \mathrm{D}+\mathrm{c} \ln \mathrm{H}$ & -1.343 & 1.890 & 0.097 & 0.998 & -5.960 & 0.036 & 0.050 & 1.001 \\
\hline \multirow{3}{*}{ Branch } & $\ln \hat{Y}=\ln a+b \ln D$ & -2.539 & 2.194 & - & 0.999 & -7.201 & 0.021 & 0.027 & 1.000 \\
\hline & $\ln \hat{Y}=\ln a+b \ln \left(D^{2} H\right)$ & 4.885 & 0.887 & - & 0.993 & -4.701 & 0.077 & 0.095 & 1.005 \\
\hline & $\ln \hat{\mathrm{Y}}=\ln \mathrm{a}+\mathrm{b} \ln \mathrm{D}+\mathrm{c} \ln \mathrm{H}$ & -2.460 & 2.235 & -0.089 & 0.999 & -7.232 & 0.018 & 0.027 & 1.000 \\
\hline Foliage & $\ln \hat{Y}=\ln a+b \ln D$ & -2.801 & 1.803 & - & 0.928 & -2.634 & 0.147 & 0.268 & 1.037 \\
\hline & $\ln \hat{Y}=\ln a+b \ln \left(D^{2} H\right)$ & 3.300 & 0.731 & - & 0.927 & -2.623 & 0.187 & 0.270 & 1.037 \\
\hline & $\ln \hat{Y}=\ln a+b \ln \mathrm{D}+\mathrm{c} \ln \mathrm{H}$ & -3.067 & 1.665 & 0.300 & 0.929 & -2.579 & 0.162 & 0.272 & 1.038 \\
\hline Total AGB & $\ln \hat{Y}=\ln a+b \ln D$ & -0.920 & 2.011 & - & 0.998 & -6.055 & 0.033 & 0.049 & 1.001 \\
\hline & $\ln \hat{Y}=\ln a+b \ln \left(D^{2} H\right)$ & 5.883 & 0.814 & - & 0.994 & -4.913 & 0.073 & 0.086 & 1.004 \\
\hline & $\ln \hat{Y}=\ln a+b \ln D+c \ln H$ & -0.972 & 1.984 & 0.059 & 0.998 & -6.001 & 0.034 & 0.049 & 1.001 \\
\hline
\end{tabular}

Note: * indicated that the $\mathrm{p}$-value for all allometric models is $<0.05$; lna, $\mathrm{b}$, and c were the fitted parameters; $\mathrm{R}^{2}$ was the coefficient of determination; AIC was Akaike information criterion; MAB was mean absolute bias; RMSE was the root mean square error, and CF was correction factor. We printed the best allometric equation for estimating biomass in every tree component and total in bold. 
In opposite condition, the utilization of model "In $\hat{Y}=$ $\ln \mathrm{a}+\mathrm{b} \times \ln \mathrm{D}+\mathrm{c} \times \ln \mathrm{H}$ " demonstrated the most accurate quantification (R2) for estimating the biomass in every tree component and a total of $T$. grandis, for the foliage and branch biomass of $M$. azedarach, for the total AGB of $S$. macrophylla, and the foliage biomass of $F$. moluccana. However, the difference of R2, AIC, MAB, and RMSE between both models only ranged 2-3\%. It indicated that the equation "ln $\hat{\mathrm{Y}}=\ln \mathrm{a}+\mathrm{b} \times \ln \mathrm{D}$ " was the best allometric equation for facilitating the accurate quantification of biomass in every tree component and total for four species. Besides having high R2 and low AIC, MBA, and RMSE, this model was also more straightforward than other equations since it only had a single predictor (D). Interestingly, biomass estimation accuracy using the best model could reach more than $90 \%$, except estimating the foliage biomass of $T$. grandis by approximately $87.8 \%$.

\section{Comparison AGB estimation between allometric esquation and BEF}

The comparison uses the allometric equation and BEF for quantifying focused biomass on estimating total AGB at the individual tree level for each species. We prepared a set of validation data from each species to assess the difference of biomass estimation using actual measurement, allometric equation, and BEF. Our study found the use of $\mathrm{BEF}$ for predicting biomass of four species resulted in a significant bias estimation, varying from 15.21-20.11\% (Table 7). Conversely, allometric equations for calculating biomass of four species generated estimation result closer to the actual measurement. The difference estimation between the allometric equation and precise measurement was $3.29-9.71 \%$. This gap was not significantly different statistically. This fact indicated that using allometric models provided better accuracy than BEF to estimate individual tree biomass in community forests, particularly in the Magetan District. However, we could apply both methods to facilitate the more efficient biomass estimation for community forests tree species. BEF could become an alternative method for estimating tree biomass in community forests when the allometric equation was not available.

\section{Discussion}

Diameter at breast height (D) was the most critical parameter for describing individual tree performance for each species. It had a strong relationship with other tree characteristics, such as height, volume, biomass, and carbon stock (Lumbres et al. 2015; Kebede and Soromessa 2018; Abrantes et al. 2019; Zhao et al. 2019). In general, a higher dimension of tree diameter indicated more significant biomass accumulation (Altanzagas et al. 2019; Zhang et al. 2019; Wirabuana et al. 2020). Therefore, this parameter generally used as the predictor variable for estimating aboveground biomass. Several studies confirmed that $\mathrm{D}$ as an independent variable in allometric models could provide good accuracy for predicting tree biomass more than $80 \%$ (Ribeiro et al. 2015; Taeroe et al. 2015; Chen et al. 2017).

This study realized that for all species, the highest biomass distribution allocated in the stem. It usually occurred since the branch was a tree component that became the main product of woody species. Moreover, this component consisted of amount cells which played an essential role in the translocation process (Aubry et al. 2019). For example, when root absorbed water and nutrients from the soil, those elements had to pass stem before distributed into leaves as raw materials in the photosynthesis process (De Schepper and Steppe 2010). Then, after producing carbohydrates from physiological activity, those assimilated had to be distributed from leaves to other tree components, including branch and roots, through the stem (Kocurek et al. 2020). It exhibited why the majority of plant biomass distributed in the stem. It directed to accelerate the process of translocation for creating more efficient metabolism activities.

In most species, particularly for species planted in plantation forests, stem biomass's relative contribution to total AGB generally improved along with the increasing diameter classes. The trend also observed in several species established in community forests. Principally, the bigger tree diameter indicated the better growth performance, in which the process of water and nutrients absorption occurred optimally (Wang et al. 2019). Thus, their biomass production was relatively higher than a tree with a lower diameter.

Table 7. Comparison mean the quantification of biomass using destructive method, allometric equation, and biomass expansion factor

\begin{tabular}{|c|c|c|c|c|c|c|}
\hline \multirow[b]{2}{*}{ Species } & \multicolumn{3}{|c|}{ Mean of AGB $(\mathrm{kg})$} & \multicolumn{3}{|c|}{ Mean Difference between (\%) } \\
\hline & $\begin{array}{c}\text { Actual } \\
\text { measurement }\end{array}$ & $\begin{array}{c}\text { Predicted by } \\
\text { BEF }\end{array}$ & $\begin{array}{c}\text { Predicted by } \\
\text { equation }\end{array}$ & Actual and BEF & $\begin{array}{c}\text { Actual and } \\
\text { equation }\end{array}$ & $\begin{array}{c}\text { BEF } \\
\text { and equation }\end{array}$ \\
\hline S. macrophylla & 244.47 & 239.86 & 245.14 & $\begin{array}{c}15.21 \\
(0.046)\end{array}$ & $\begin{array}{c}5.19 \\
(0.764)\end{array}$ & $\begin{array}{c}17.99 \\
(0.029)\end{array}$ \\
\hline T. grandis & 173.31 & 184.18 & 171.49 & $\begin{array}{c}16.02 \\
(0.034)\end{array}$ & $\begin{array}{c}8.33 \\
(0.502)\end{array}$ & $\begin{array}{c}16.52 \\
(0.035)\end{array}$ \\
\hline F. moluccana & 56.56 & 58.33 & 57.39 & $\begin{array}{l}16.69 \\
(0.038)\end{array}$ & $\begin{array}{c}9.71 \\
(0.343)\end{array}$ & $\begin{array}{c}10.93 \\
(0.049)\end{array}$ \\
\hline M. azedarach & 326.36 & 315.72 & 326.34 & $\begin{array}{c}20.11 \\
(0.048)\end{array}$ & $\begin{array}{c}3.29 \\
(0.994)\end{array}$ & $\begin{array}{c}23.76 \\
(0.004)\end{array}$ \\
\hline
\end{tabular}


However, this study recorded the relative contribution of stem biomass to the total AGB rather varied in each species. For $F$. moluccana and $S$. macrophylla, the biomass proportion in stem increased with the rising diameter classes, while the opposite trend recorded in the relative contribution of stem biomass to the total AGB for $T$. grandis and $M$. azedarach. This trend caused by the different accumulation of branch biomass in every diameter class for each species. Branch biomass production is highly related to crown development (Pinkard and Beadle 1998), Where: this stage is principally associated with tree competition. Higher tree competition would generate lower crown volume because there was limited space for branch development (Silva et al. 2014). Several studies have confirmed that Indonesia's community forests consisted of multispecies with irregular distribution of age, spacing, and growth (Amirta et al. 2016; Boedhihartono 2017; Setiahadi 2017; Wulandari et al. 2018). This situation became the primary factor why the relative contribution of branch biomass to total AGB was very fluctuating in every species at different diameter classes.

This study documented that wood density and BEF's value relatively varied in every individual tree from different species; due to the other growth performances of every species in the community forest. More significant tree dimensions frequently resulted in greater wood density and BEF since it accumulated higher wood volume and biomass production. The previous studies explained the value of wood density and BEF for tree species was affected by the variation of age, growth, and site quality (Petersson et al. 2012; Seo et al. 2013; Lisboa et al. 2018). Interestingly, the average BEF for S. macrophylla (1.41) and $F$. moluccana $(1.38)$ in this study relatively higher than the BEF from a previous study in Indonesia for those species, whereas the value of BEF for S. macrophylla and $F$. moluccana of the prior research for each reached 1.36 and 1.38 (Krisnawati et al. 2012). On the other hand, the average BEF for $T$. grandis in this research is substantially lower than the mean BEF from the previous study by approximately 1.46 (Krisnawati et al. 2012).

This study demonstrated that the equation "ln $\hat{Y}=\operatorname{lna}+$ b $x \operatorname{lnD}$ " was the best model for facilitating the aboveground biomass estimation at every tree component and total for four species. Besides providing high accuracy, this model was the most straightforward equation since it was only used $\mathrm{D}$ as the single predictor variable. The simple model for estimating biomass in community forests tree species was necessary because of the stand condition of community forests in Indonesia, particularly in Magetan, which consisting of multispecies with a high variation in growth and age distribution (Wirabuana et al. 2020). Moreover, the spacing among trees in community forests was not consistent because the landowners did not conduct spacing management. Thus, tree height measurement had a high potential for bias due to the problematic situation for determining each species' top crown. Several studies also reported that tree diameter was the best predictor variable for constructing the allometric equation for community forests tree species (Karyati et al. 2021; Wirabuana et al. 2020).
The results indicated using allometric equations provided a more accurate estimation. Then BEF for supporting the biomass quantification in community forests. The previous studies also confirmed a similar result Where: the utilization of BEF for estimating tree biomass demonstrated lower accuracy than allometric models. The estimation of tree biomass using BEF indicated smaller accuracy. The expansion factor's value in every tree influenced by specific characteristics, such as age distribution and site quality (Hernández-Ramos et al. 2017). A study report that BEF's value gradually declined along with the increasing tree age (Petersson et al. 2012).

Meanwhile, the BEF of tree species commonly higher in the excellent site than the poor site (Teobaldelli et al. 2009). However, we could apply both methods to facilitate the quantification of biomass in community forests. But, to obtain a more accurate estimation, the use of an allometric equation was more recommended.

In conclusion, most tree species of community forests at Magetan accumulated their highest biomass production in the stem, followed by branch and foliage. The relative contribution of every tree component to total AGB highly varied along with the increasing diameter classes. Nevertheless, the proportion of stem biomass to total AGB in each diameter class still higher than branch and foliage. For every species, the value of wood density and BEF principally varied and had an extensive range for four species. The best allometric model for estimating aboveground biomass in every tree component and a total individual tree was "ln $\hat{\mathrm{Y}}=\ln \mathrm{a}+\mathrm{b} \times \ln \mathrm{D}$ ", with having high accuracy of more than $80 \%$. An allometric equation for estimating the biomass of community forests tree species demonstrated better accuracy than BEF. Therefore, more recommended this approach to support the biomass estimation in community forests.

\section{ACKNOWLEDGEMENTS}

Authors are very grateful to the village government in every location of community forest that allowed to conduct this study. We also express our gratitude to anonymous reviewers for their suggestions to improve the quality of this article.

\section{REFERENCES}

Abrantes KKB, Paiva LM, De Almeida RG, Urbano E, Ferreira AD, Mazucheli J. 2019. Modeling the individual height and volume of two integrated crop-livestock-forest systems of Eucalyptus spp. in the Brazilian Savannah. Acta Sci 41: 1-8. DOI: 10.4025/actasciagron.v41i1.42626.

Altanzagas B, Luo Y, Altansukh B, Dorjsuren C, Fang J, Hu H. 2019. Allometric equations for estimating the above-ground biomass of five forest tree species in Khangai, Mongolia. Forests 10 (8): 1-17. DOI: 10.7226/jtfm.27.1.24.

Amirta R, Y uliansyah Y, Angi EM, Ananto BR, Setiyono B, Haqiqi MT, Septians GA, Lodong M, Oktavianto RN. 2016. Plant diversity and energy potency of community forestin East Kalimantan, Indonesia: Searching for fast growing wood species for energy production. Nusantara Biosci 8 (1): 22-31. DOI: 10.13057/nusbiosci/N080106. 
Aubry E, Dinant S, Vilaine F, Bellini C, Le Hir R. 2019. Lateral transport of organic and inorganic solutes. Plants 8 (1): 1-25. DOI: 10.3390/plants8010020

Besar NA, Suardi H, Phua MH, James D, Mokhtar MB, Ahmed MF 2020. Carbon stock and sequestration potential of an agroforestry system in Sabah, Malaysia. Forests 11 (2): 1-16. DOI: 10.3390/f11020210

Boedhihartono AK. 2017. Can community forests be compatible with biodiversity conservation in Indonesia? Land 6 (1): 1-17. DOI: 10.3390/land6010021

Bouriaud O, Don A, Janssens IA, Marin G, Schulze ED. 2019. Effects of forest management on biomass stocks in romanian beech forests. For Ecosyst 6 (1): 1-15. Doi: 10.1186/s40663-019-0180-4

Chen D, Huang X, Zhang S, Sun X. 2017. Biomass modeling of larch (Larix spp.) plantations in China based on the mixed model, dummy variable model, and Bayesian hierarchical model. Forests 8 (8): 5-8. DOI: $10.3390 / \mathrm{f} 8080268$

de Andrés EG. 2019. Interactions between climate and nutrient cycles on forest response to global change: The role of mixed forests. Forests 10 (8): 609. DOI: 10.3390/f10080609

De Schepper V, Steppe K. 2010. Development and verification of a water and sugar transport model using measured stem diameter variations. J Exp Bot 61 (8): 2083-2099. DOI: 10.1093/jxb/erq018

Ekoungoulou R, Niu S, Joël Loumeto J, Averti Ifo S, Enock Bocko Y, Mikieleko F, Eusebe DM, Senou H, Liu X. 2015. Evaluating the carbon stock in above-and below- ground biomass in a moist Central African forest. Appl Ecol Environ Sci 3 (2): 51-59.

Ghasemi A, Zahediasl S. 2012. Normality tests for statistical analysis: A guide for non-statisticians. Int J Endocrinol Metab 10 (2): 486-489. DOI: 10.5812 /ijem.3505

González-García M, Hevia A, Majada J, Barrio-Anta M. 2013. Aboveground biomass estimation at tree and stand level forshort rotation plantations of Eucalyptus nitens (Deane \& Maiden) Maiden in Northwest Spain. Biomass Bioenergy 54: 147-157. DOI: 10.1016/j.biombioe.2013.03.019

Guendehou GHS, Lehtonen A, Moudachirou M, Mäkipää R, Sinsin B. 2012. Stem biomass and volume models of selected tropical tree species in West Africa. South For 74 (2): 77-88. DOI: 10.2989/20702620.2012.701432

Hakamada R, Hubbard RM, Ferraz S, Stape JL. 2017. Biomass production and potential water stress increase with planting density in four highly productive clonal Eucalyptus genotypes. South For J For Sci 79 (3): 251-257. DOI: 10.2989/20702620.2016.1256041

Han SH, Park BB. 2020. Comparison of allometric equation and destructive measurement of carbon storage of naturally regenerated understory in a Pinus rigida plantation in South Korea. Forests 11 (4): 1-11. DOI: 10.3390/f11040425

He H, Zhang C, Zhao X, Fousseni F, Wang J, Dai H, Yang S, Zuo Q. 2018. Allometric biomass equations for 12 tree species in coniferous and broadleaved mixed forests, Northeastern China. PLoS One 13 (1): 1-16. DOI: 10.1371/journal.pone.0186226

Hernández-Ramos J, De los Santos-Posadas HM, Valdez-Lazalde JR, Tamarit-Urias JC, Ángeles-Pérez G, Hernández-Ramos A, Peduzzi A, Carrero O. 2017. Biomasa aérea y factores de expansión en plantaciones forestales comerciales de Eucalyptus urophylla S. T. Blake. Agrociencia 51 (8): 921-938.

Issa S, Dahy B, Ksiksi T, Saleous N. 2020. A review of terrestrial carbon assessment methods using geo-spatial technologies with emphasis on arid lands. Remote Sens 12 (12): 1-32. DOI: 10.3390/rs12122008

Karyati, Widiati KY, Karmini, Mulyadi R. 2021. The allometric relationships for estimating above-ground biomass and carbon stock in an abandoned traditional garden in East Kalimantan, Indonesia. Biodiversitas 22: 751-762. DOI: 10.13057/biodiv/d220228

Kebede B, Soromessa T. 2018. Allometric equations for aboveground biomass estimation of Olea europaea L. subsp. cuspidata in Mana Angetu Forest. Ecosyst Heal Sustain 4 (1): 1-12. DOI: 10.1080/20964129.2018.1433951

Ketterings QM, Coe R, Van Noordwijk M, Ambagau' Y, Palm CA. 2001 Reducing uncertainty in the use of allometric biomass equations for predicting above-ground tree biomass in mixed secondary forests. For Ecol Manag 146 (1-3: 199-209. DOI: 10.1016/S0378-1127(00)004606

Kim C, Baek G, Yoo BO, Jung SY, Lee KS, An KW. 2019. Comparison of allometric equations and biomass expansion factors for six evergreen broad-leaved trees in subtropical forests in southern Korea. J Sustain For 38 (3): 199-212. DOI: 10.1080/10549811.2018.1528157
Kocurek M, Kornas A, Wierzchnicki R, Lüttge U, Miszalski Z. 2020. Importance of stem photosynthesis in plant carbon allocation of Clusia minor. Trees Struct Funct 34 (4): 1009-1020. DOI: 10.1007/s00468-020-01977-w

Kora SH, Guendehou GS, Goussanou CA, Assogbadjo AE, Sinsin B. 2019. Allometric equations from a non-destructive approach for biomass prediction in natural forest and plantation in West Africa. South For 81 (2): 111-122. DOI: 10.2989/20702620.2018.1512795

Krejza J, Světlík J, Bednář P. 2017. Allometric relationship and biomass expansion factors (BEFs) for above- and below-ground biomass prediction and stem volume estimation for ash (Fraxinus excelsior L.) and oak (Quercus robur L.). Trees Struct Funct 31 (4): 1303-1316. DOI: $10.1007 / \mathrm{s} 00468-017-1549-\mathrm{z}$

Krisnawati H, Agency D, Agency D, Imanuddin R, Agency D. 2012. Monograph allometric models for estimating tree biomass at various ecosystems types in Indonesia. Ministry of Forestry, Bogor. [Indonesian]

Krisnawati H, Imanuddin R, Adinugroho WC. 2012. Monograf allometric models for estimating tree biomass at various forest ecosystems types in Indonesia. Center for research and development of conservation and rehabilitation, Ministry of Forestry, Bogor. [Indonesian]

Lisboa SN, Guedes BS, Ribeiro N, Sitoe A. 2018. Biomass allometric equation and expansion factor for a mountain moist evergreen forest in Mozambique. Carbon Balance Manag 13 (1): 1-16. DOI: 10.1186/s13021-018-0111-7.

Lu K, Bi H, Watt D, Strandgard M, Li Y. 2018. Reconstructing the size of individual trees using log data from cut-to-length harvesters in Pinus radiata plantations: a case study in NSW, Australia. J For Res 29 (1): 13-33. DOI: 10.1007/s11676-017-0517-1.

Lumbres RIC, Lee YJ, Yun CW, Koo CD, Kim SB, Son YM, Lee KH, Won HK, Jung SC, Seo YO. 2015. DBH-height modeling and validation for Acacia mangium and Eucalyptus pellita in Korintiga Hutani Plantation, Kalimantan, Indonesia. For Sci Technol 11 (3): 119-125. DOI: 10.1080/21580103.2014.957356.

Mahmood H, Siddique MRH, Abdullah SMR, Islam SMZ, Matieu H, Iqbal MZ, Akhter M. 2020. Semi-destructive method to derive allometric aboveground biomass model for village forest of Bangladesh: Comparison of regional and pan-tropical models. J Trop For Sci 32 (3): 246-256. DOI: 10.26525/jtfs2020.32.3.246.

Mishra P, Pandey CM, Singh U. 2019. Descriptive statistics and normality tests for statistical data. Ann Card Anaesth 22 (1): 67-72. DOI: $10.4103 \% 2$ Faca.ACA_157_18.

Nunes LJR, Meireles CIR, Gomes CJP, Ribeiro NMCA. 2019. Forest management and climate change mitigation: A review on carbon cycle flow models for the sustainability of resources. Sustainability 11 (19): 1-10. DOI: 10.3390/su11195276.

Nunes LJR, Meireles CIR, Gomes CJP, Ribeiro NMCA. 2020. Forest contribution to climate change mitigation: Management oriented to carbon capture and storage. Climate 8 (2): 1-20. DOI: 10.3390/cli8020021.

Petersson H, Holm S, Ståhl G, Alger D, Fridman J, Lehtonen A, Lundström A, Mäkipää R. 2012. Individual tree biomass equations or biomass expansion factors for assessment of carbon stock changes in living biomass - A comparative study. For Ecol Manag 270: 78-84. DOI: 10.1016/j.foreco.2012.01.004.

Pinkard EA, Beadle CL. 1998. Aboveground biomass partitioning and crown architecture of Eucalyptus nitens following green pruning. Can J For Res 28 (9): 1419-1428. DOI: 10.1139/cjfr-28-9-1419.

Reichstein M, Carvalhais N. 2019. Aspects of forest biomass in the earth system: Its role and major unknowns. Surv Geophys 40 (4): 693-707. DOI: 10.1007/s10712-019-09551-x.

Ribeiro SC, Soares CPB, Fehrmann L, Jacovine LAG, von Gadow K. 2015. Aboveground and belowground biomass and carbon estimates for clonal Eucalyptus trees in Southeast Brazil. Rev Árvore 39: 353363. DOI: 10.1590/0100-67622015000200015

Sadono R, Wardhana W, Wirabuana PYAP, Idris F. 2020. Productivity evaluation of Eucalyptus urophylla plantation established in dryland ecosystems, East Nusa Tenggara. J Degrad Min Lands Manag 8 (1): 2502-2458. DOI: 10.15243/jdmlm.2020.081.2461

Sadono R, Wardhana W, Wirabuana PYAP, Idris F. 2021. Allometric equations for estimating aboveground biomass of Eucalytpus urophylla S.T. Blake in East Nusa Tenggara. J Trop For Manag 27 (1): 24-31. DOI: 10.7226/jtfm.27.1.24.

Seo YO, Lee YJ, Lumbres RIC, Pyo JK, Kim RH, Son YM, Lee KH. 2013. Influence of stand age class on biomass expansion factor and 
allometric equations for Pinus rigida plantations in South Korea. Scand J For Res 28 (6): 566573. DOI: 10.1080/02827581.2013.786126.

Setiahadi R. 2017. How significant is the existence of forest community contribution in GHG emissions reduction? J Eng Appl Sci 12 (19): 4826-4830. DOI: $10.36478 /$ jeasci.2017.4826.4830.

Silva PSL e, Paiva HN de, Oliveira VR de, Siqueira PL de OF, Soares EB, Monteiro AL, Tavella LB. 2014. Biomass of tree species as a response to planting density and interspecific competition. Rev Árvore 38: 319-329. DOI: 10.1590/S0100-67622014000200012.

Stas SM, Rutishauser E, Chave J, Anten NPR, Laumonier Y. 2017. Estimating the aboveground biomass in an old secondary forest on limestone in the Moluccas, Indonesia: Comparing locally developed versus existing allometric models. For Ecol Manag 389: 27-34. DOI: 10.1016/j.foreco.2016.12.010.

Taeroe A, Nord-Larsen T, Stupak I, Raulund-Rasmussen K. 2015. Allometric biomass, biomass expansion factor and wood density models for the OP42 hybrid poplar in Southern Scandinavia Bioenergy Res 8 (3): 1332-1343. DOI: 10.1007/s12155-015-9592-3.

Teobaldelli M, Somogyi Z, Migliavacca M, Usoltsev VA. 2009. Generalized functions of biomass expansion factors for conifers and broadleaved by stand age, growing stock and site index. For Ecol Manag 257 (3): 1004-1013. DOI: 10.1016/j.foreco.2008.11.002.

Tetemke BA, Birhane E, Rannestad MM, Eid T. 2019. Allometric models for predicting aboveground biomass of trees in the dry afromontane forests of Northern Ethiopia. Forests 10 (12): 1-15. DOI $10.3390 / f 10121114$

Viera M, Rodríguez-Soalleiro R. 2019. A complete assessment of carbon stocks in above and belowground biomass components of a hybrid Eucalyptus plantation in Southern Brazil. Forests 10 (7): 1-12. DOI 10.3390/f10070536.
Wang Z, Du A, Xu Y, Zhu W, Zhang J. 2019. Factors limiting the growth of eucalyptus and the characteristics of growth and water use under water and fertilizer management in the dry season of Leizhou $\begin{array}{lllll}\text { Peninsula, } & \text { China. Agronomy } 9 & \text { (10): 1-17. } & \text { DOI: }\end{array}$ 10.3390/agronomy9100590.

Wirabuana PYAP, Sadono R, Jurniarso S. 2019. Fertilization effects on early growth, aboveground biomass, carbon storage, and leaf characteristics of Eucalyptus pellita F.Muell. in South Sumatra. J Manajemen Hutan Tropika 25 (3): 154-163. DOI: 10.7226/jtfm.25.3.154 [Indonesian]

Wirabuana PYAP, Setiahadi R, Sadono R, Lukito M, Martono DS, Matatula J. 2020. Allometric equations for estimating biomass of community forest tree species in Madiun, Indonesia. Biodiversitas 21 (19): 4291-4300. DOI: 10.13057/biodiv/d210947.

Wulandari C, Bintoro A, Rusita, Santoso T, Duryat, Kaskoyo H, Erwin, Budiono P. 2018. Community forestry adoption based on multipurpose tree species diversity towards to sustainable forest management in ICEF of University of Lampung, Indonesia. Biodiversitas 19 (3): 1102-1109. DOI: 10.13057/biodiv/d190344.

Xue Y, Yang Z, Wang X, Lin Z, Li D, Su S. 2016. Tree biomass allocation and its model additivity for Casuarina equisetifolia in a tropical forest of Hainan Island, China. PLoS One 11 (3): 1-20. DOI: 10.1371/journal.pone.0151858.

Zhang X, Zhang X, Han H, Shi Z, Yang X. 2019. Biomass accumulation and carbon sequestration in an age-sequence of Mongolian pine plantations in Horqin sandy land, China. Forests 10 (2): 1-18. DOI: 10.3390/f10020197.

Zhao H, Li Z, Zhou G, Qiu Z, Wu Z. 2019. Site-specific allometric models for prediction of above-and belowground biomass of subtropical forests in Guangzhou, Southern China. Forests 10 (10): 116. DOI: $10.3390 / f 10100862$ 